\title{
Inheritance of Scarlet Color and Vein Pattern in Flowers and Oxblood Red Seedcoat Color Derived from the Interspecific Cross of Common Bean with Scarlet Runner Bean (Phaseolus coccineus L.)
}

\author{
Mark J. Bassett ${ }^{1}$ \\ Horticultural Sciences Department, University of Florida, Gainesville, FL 32611
}

AdDitional Index words. Phaseolus vulgaris, seedcoat genetics, genetic linkage, pleiotropy

Aвstract. The genetics of the vermilion flower color (more orange than scarlet or salmon red) of Phaseolus coccineus L. is largely unknown, but the gene Sal for salmon red is the gene essential for its expression. Lamprecht line M0169 (PI 527868) expresses salmon red flowers with vein pattern on the wing petals and black seedcoats. M0169 (Sal Am and an unknown gene that inhibits the scarlet flower color expression of $\mathrm{Am}$ ) was crossed with $v \mathrm{BC}_{3} \mathbf{5 - 5 9 3}$ (sal am and no inhibitor gene, expressing white flowers and mineral brown seedcoats). Line 5-593 is a Florida dry bean (Phaseolus vulgaris L.) line used as the recurrent parent for development of genetic stocks. The $\mathrm{F}_{2}$ from $\mathrm{Sal} \mathrm{Am} \mathrm{Vwf} \mathrm{BC}_{1} \mathbf{5 - 5 9 3}$ (scarlet flowers, black seedcoats) $\mathrm{X} v \mathrm{BC}_{3}$ 5-593 (white flowers, mineral brown seedcoats) supported the hypothesis that a partly dominant gene $A m$ changes salmon red to scarlet flower color and that $A m$ has no expression with sal. The $\mathrm{F}_{3}$ progeny test of 27 random $\mathrm{F}_{2}$ parents from the above cross supported the hypothesis of a single partly dominant factor (Am) with no expression without $\mathrm{Sal}$, where only $\mathrm{Sal} / \mathrm{Sal} \mathrm{Am} / \mathrm{Am}$ completely eliminates the flower vein pattern (VP) of $\mathrm{Sal}$. F $\mathrm{F}_{4}$ progeny tests of 29 random $\mathrm{F}_{3}$ parents derived from a $\mathrm{F}_{2}$ selection with $\mathrm{Sal} / \mathrm{Sal} \mathrm{Am/am} \mathrm{Vw} / v$ supported the hypothesis that Am is linked to $V(\mathrm{cM}=9.4 \pm 1.93)$ and the hypothesis that $\mathrm{Am}$ is linked with a dominant gene (tentative symbol $\mathrm{Oxb})$ that (with $\mathrm{Sal} v$ ) changes seedcoat color from mineral brown with red haze to oxblood red. Another $\mathrm{F}_{4}$ progeny test of seven selected $\mathrm{F}_{3}$ parents with $\mathrm{Sal} / \mathrm{Sal} \mathrm{Am/am} \mathrm{v/v} \mathrm{and} \mathrm{oxblood} \mathrm{seedcoat} \mathrm{color} \mathrm{supported} \mathrm{the} \mathrm{hypothesis} \mathrm{that} \mathrm{the} \mathrm{Oxb} \mathrm{gene} \mathrm{(linked} \mathrm{with} A m$ and derived from M0169) with Sal $v$ expresses oxblood seedcoat color. The gene symbol Am is proposed for the gene from M0169 that with Sal $v$ expresses two pleiotropic effects: changes salmon red to scarlet flower color and eliminates the VP of salmon red. The interaction of $\mathrm{Sal}$ with $\mathrm{Am}$ for flower color and VP expression is discussed for all gene combinations.

Lamprecht (1940) described 10 red flower color classes derived from interspecific crosses between common bean (Phaseolus vulgaris L.) and scarlet runner bean (Phaseolus coccineus L.), which he referred to as $P$. multiflorus Lam. The flower classes included three intensities of expression, described as red, rose and pale rose, of three basic colors, viz., salmon, begonia, and amaranth. He also described a scarlet class and the color pattern class observed in 'Painted Lady', a P. coccineus stock. Genetic interpretation of those classes was not provided.

In a subsequent paper, Lamprecht (1948) proposed the genetic hypothesis that the scarlet flower color of $P$. coccineus (the typical vermilion flower of that species) is controlled by the interaction of fourgenes, Sal, Am, Beg, and No. The segregation data for red flowers provided by Lamprecht (1948) did not explore any of the possible interactions among the proposed genes and did not establish them as independent genes. Regrettably, all of the genetic stocks developed by Lamprecht with the genes Am, Beg, and No have been lost, but stocks with genotype notations for $\mathrm{Sal}$ are still extant.

Over the past 15 years, I have been developing, on a $P$. vulgaris genetic background, replacements for the red flower color stocks lost from the Lamprecht collection. All the basic (true breeding) color classes of Lamprecht $(1940,1948)$ have been recreated except for nopal red (Bassett, unpublished data). I describe the typical $P$. coccineus flower color as vermilion, and the slightly less orange color studied in this paper as scarlet. This paper presents data supporting the hypotheses 1) that scarlet flower color without vein pattern is controlled by two genes, viz., Sal and $A m$ (with $V_{\text {wf }}$ or $v$ ) and 2) that oxblood red seedcoat color is controlled by a dominant gene (tentative symbol $O x b$ ) closely linked to $A m$ (with $S a l v$ ).

Received for publication 11 Apr. 2003. Accepted for publication 1 May 2003 This research was supported by the Florida Agricultural Experiment Station and a T-STAR grant, and approved for publication as journal series R-09077. ${ }^{1}$ Professor.
Materials and Methods

Flower color names and numeric designations used in this paper are derived from the Horticultural Colour Charts of the Royal Horticultural Society (RHS Charts), 1938 edition. Some of those flower colors will also be given in the new notation derived from the recently revised Royal Horticultural Society color identification system (copyright, 2001) presented on color fans (RHS Fans).

Florida dry bean breeding line 5-593, and its $v \mathrm{BC}_{3} 5-593$ derivative, were used as the recurrent parents for the transfer of flower color genes from the Lamprecht line M0169 into the 5-593 common bean genetic background. The "M" in M0169 stands for multigaris, which indicates a line derived from a cross between $P$. vulgaris and $P$. coccineus. Line 5-593 carries the $V$ gene for bishops violet flowers, but it does not carry the gene Sal for salmon red flower color or the gene Am for scarlet flower color, which in nature are found only in $P$. coccineus. Salmon red is a less orange color than scarlet. The black seedcoats of 5-593 are the expression of the genotype $P[C r] J G B V$ (Bassett, 1994).

According to the genetic notes left by Lamprecht (personal communication from Stig Blixt of Sweden), line M0169 (now PI 527858) carries only Sal for its salmon red flower color, but M0169 also carries the gene Am cryptically (data presented below). M0169 has black seedcoats, which if they were the expression of $V$ (with other seedcoat genes), would produce China rose flowers (Bassett et al., 1990). Thus, there is no doubt that M0169 also carries the gene $V^{\mathrm{wf}}$, which permits black seedcoat expression without any anthocyanin expression in the flowers (Bassett, 1997).

The following speculative hypothesis is offered to explain how M0169 carries genotype $\mathrm{Sal} \mathrm{Am}$ without expressing scarlet flowers. There may be a recessive inhibitor gene in M0169 that blocks Am expression, which is analogous to the recessive epistasis factor in $P$. coccineus that prevents expression of the gene $r f$ for 
reclining foliage commonly found in scarlet runner bean (Bassett, 1976). The salmon red flowers of M0169 have another important character not noted by Lamprecht (1948). The wing petals have patterned color along the veins, i.e., the veins are distinctly more pale than salmon red (sometimes almost white). This pattern in the wing petals will be referred to as vein pattern (VP) in this paper.

In 1987, the $\mathrm{F}_{2}$ from the cross 5-593 x M0169 was grown in the field at Gainesville, and selection for a plant with scarlet flower color was made. No data were recorded for flower color segregation in the $\mathrm{F}_{2}$. In the greenhouse, 5-593 was crossed to a $\mathrm{F}_{3}$ progeny plant with scarlet $19 / 0$ flower color. The $F_{2}$ from the latter cross was grown in the field in 1988, and a selection for scarlet flowers was made. A true breeding $\mathrm{F}_{3}$ progeny was grown in the greenhouse in 1989 , and the true breeding status was confirmed in the field in the $\mathrm{BC}_{1}-\mathrm{F}_{4}$ progeny in 1990 . The tentative genetic hypothesis for its flower color and black seedcoats is Sal Am $V^{\text {wf }}$. In Fall 1990, the cross $\mathrm{Sal} \mathrm{Am} V^{\mathrm{wf}} \mathrm{BC}_{1}$ 5-593 x $v \mathrm{BC}_{3}$ 5-593 (sal am, white flowers and mineral brown seedcoats) was made, and data were recorded for flower color in the $F_{1}$ and $F_{2}$ progeny in 1991.

My hypothesis is that 5-593 does not carry the hypothetical gene in M0169 that inhibits Am expression. Thus, by means of backcrossing $A m$ to 5-593 and selecting for scarlet flower color, the genetic stock Sal Am $V^{\mathrm{wf}} \mathrm{BC}_{1}$ 5-593 was made homozygous for the wild type allele in 5-593 that permits scarlet flower color expression.

Remnant $\mathrm{F}_{2}$ seed of the cross SalAm $V^{\mathrm{wf}} \mathrm{BC}_{1} 5-593 \times v \mathrm{BC}_{3} 5-593$ (sal am) was used to grow a 27-plant progeny in the greenhouse in Fall 2000, and the $F_{3}$ progeny tests were grown in the field in Spring 2001. Data were recorded for flower and seedcoat color in $\mathrm{F}_{2}$ and $\mathrm{F}_{3}$. Classification of red flowers in the field was done by means of tagging all fluorescent red flower plants as scarlet, vs. all untagged red flower plants. Also, notes were recorded for the presence or absence of salmon red and intermediate red segregation in each plot. The term intermediate red refers to a range of perceived hues (between scarlet and salmon red) due primarily to degrees of VP expression, where the very small differences in hue cannot be classified. RHS Charts were used in the greenhouse to classify the $\mathrm{F}_{2}$ into three red flower classes: scarlet, intermediate red, and salmon red. Two of the $\mathrm{BC}_{2}-\mathrm{F}_{2}$ progeny (designated Am-20 and Am-21) from the cross Sal Am $V^{\text {wf }} \mathrm{BC}_{1} 5-593 \times v \mathrm{BC}_{3} 5-593$ (sal $\mathrm{am}$ ) had scarlet flowers, which subsequent progeny tests in Spring 2001 demonstrated to have genotype Sal/Sal Am/am Vwf $/ v$, i.e., there was segregation for salmon red flowers but not white flowers, and there was segregation for black, mineral brown, and oxblood seedcoat colors (data not shown).

The crosses $v \mathrm{BC}_{3}$ 5-593 $\times$ Am-20 and Am-21 were made in Fall 2000. The $F_{2}$ from the cross with Am-20 was grown in the field in Spring 2001, and an $\mathrm{F}_{2}$ selection was made for a plant with $\mathrm{Sal} / \mathrm{Sal}$ $\mathrm{Am} / \mathrm{am} \mathrm{Vwf}_{\mathrm{wf}} \mathrm{v}$. A29-plant $\mathrm{BC}_{3}-\mathrm{F}_{3}$ from the cross with Am-20 was grown from remnant $\mathrm{F}_{2}$ seed and classified for flower and seedcoat color in the greenhouse in Winter 2002. The $\mathrm{F}_{4}$ was grown in the field in Spring 2002. Data were recorded for flower and seedcoat color in $F_{3}$ and $\mathrm{F}_{4}$. In $\mathrm{F}_{3}$ (greenhouse), the flower color was classified as scarlet, intermediate red, or salmon red, whereas in the $\mathrm{F}_{4}$ (field) flower color was restricted to two classes, other red (scarlet and intermediate red) or salmon red. Linkage calculation for the segregation at the $A m$ and
$V$ loci was made using the chi-square test of significance given by Mather (1957), and the map distance calculation used the maximum likelihood tables of Allard (1956).

From the cross $v \mathrm{BC}_{3} 5-593 \times \mathrm{Am}-21$, an $\mathrm{F}_{2}$ selection for scarlet flowers and oxblood seedcoats was made in Spring 2001. The $F_{3}$ progeny were grown in the greenhouse in Winter 2002 and classified for flower and seedcoat color. Selection was made for seven plants with oxblood seedcoat color and intermediate red flowers, i.e., between true scarlet and salmon red. The $\mathrm{BC}_{3}-\mathrm{F}_{4}$ progeny were grown in the field in Spring 2002, and data were recorded for flower and seedcoat colors.

\section{Results and Discussion}

The $\mathrm{F}_{2}$ from the cross $\mathrm{Sal} A m V^{\mathrm{wf}} \mathrm{BC}_{1} 5-593 \times v \mathrm{BC}_{3} 5-593$ (sal am) segregated for four flower color classes (Table 1). The genetic model proposed did not fit the data due in part to disturbed segregation at $\mathrm{Sal}$. The disturbance of random segregation at $\mathrm{Sal}$ for the cross 5-593 x M0169 was previously reported to be due to a gametophyte factor (Bassett et al., 1990). In spite of disturbed segregation, the appearance of a white flower class is interpreted as evidence that $\mathrm{Am}$ had no expression without Sal. The data for the scarlet and intermediate red flower color classes were combined because the class boundary was too difficult to establish in the field without classification errors due especially to VP effects (Table 1). The genetic interpretation is that variable expressivity of Sal/Sal Am/am does not permit accurate classification of this genotype in the field. Such difficulties notwithstanding, the genetic model tested predicts that the white flower class will be true breeding in $\mathrm{F}_{3}$ progeny tests and that the salmon red class will never segregate for scarlet or intermediate red flowers in $\mathrm{F}_{3}$ progeny tests.

To test and improve the genetic model presented in Table 1, extensive progeny testing of parental plants with exactly classified flower colors was undertaken. Twenty-seven randomly selected $\mathrm{F}_{2}$ parents from the cross $\mathrm{Sal} \mathrm{Am} V^{\mathrm{wf}} \mathrm{BC}_{1} 5-593 \times v \mathrm{BC}_{3} 5-593$ (sal am) were progeny tested in $\mathrm{F}_{3}$ for flower color segregation (Table 2). The 27 progenies fell into five categories: some segregated into various classes, whereas others were true breeding (data not shown fully). The $\mathrm{F}_{3}$ data were summarized as numbers of progenies for each category of segregation (Table 2 ). The seven $\mathrm{F}_{2}$ parents with white flowers were true breeding in $\mathrm{F}_{3}$. Those results support the hypothesis that $\mathrm{Am}$ has no red flower color expression in the absence of Sal. Of the five $\mathrm{F}_{2}$ parents with salmon red flowers, two $(\mathrm{Sal} / \mathrm{Sal})$ were true breeding in $\mathrm{F}_{3}$ and three $(\mathrm{Sal} / \mathrm{sal})$ segregated only for salmon red or white flowers (Table 2, data not fully shown). Four $\mathrm{F}_{2}$ parents (all $\mathrm{Sal} / \mathrm{Sal}$ ) were classified as scarlet flowers, but only two were true breeding in $\mathrm{F}_{3}$ (data not shown). The remaining two $\mathrm{F}_{2}$ parents with scarlet flowers segregated in $\mathrm{F}_{3}$ for salmon red progeny but no white flower progeny; hence, they must carry the genotype $\mathrm{Sal} / \mathrm{Sal} \mathrm{Am/am}$ rather than the expected genotype Sal/Sal $A m / A m$ (data not shown). Thus, the genetic hypothesis developed from the $\mathrm{F}_{2}$ data (Table 1) concerning the variable expressivity (and ambiguous classification) for the genotype Sal/Sal Am/am for scarlet flower color was confirmed.

The $11 \mathrm{~F}_{2}$ parents with intermediate red flower color (Table 2)

Table 1. Segregation for flower color in the $\mathrm{F}_{2}$ from the cross $\mathrm{Sal} \mathrm{Am} \mathrm{Vwf}^{\mathrm{wf}} \mathrm{BC}_{1} 5-593 \times v \mathrm{BC}_{3} 5-593$ (sal am).

\begin{tabular}{|c|c|c|c|c|}
\hline \multicolumn{2}{|l|}{ Sal /- } & \multicolumn{3}{|l|}{ sal/sal } \\
\hline$A m /-$ & $\mathrm{am} / \mathrm{am}$ & $-/-$ & $\chi^{2}$ & \\
\hline Scarlet or intermediate red & Salmon red & White & $9: 3: 4^{z}$ & $P$ \\
\hline 168 & 57 & 120 & 17.6 & $<0.001$ \\
\hline
\end{tabular}

zConsidering the data over the segregation at $A m$ within the $S a l /$ - classes gives 168,57 , for which the $\chi^{2}(3: 1)=0.01, P=0.91$. 
Table 2. Genetic hypothesis for flower color and vein pattern for 27 randomly selected $\mathrm{F}_{2}$ parents from the cross $\operatorname{Sal} A m V^{\mathrm{wf}} \mathrm{BC}_{1} 5-593 \times v \mathrm{BC}_{3}$ 5-593 ( $\mathrm{sal} \mathrm{am}$ ), based on $\mathrm{F}_{3}$ progeny test data.

\begin{tabular}{|c|c|c|c|c|}
\hline Flower color and & No. of & \multicolumn{3}{|c|}{$\mathrm{F}_{3}$ segregation for flower color and pattern } \\
\hline $\begin{array}{l}\text { genotypes in } \\
\mathrm{F}_{2} \text { parents }\end{array}$ & $\begin{array}{c}\mathrm{F}_{3} \\
\text { progenies }^{\mathrm{z}}\end{array}$ & $\begin{array}{l}\text { All red } \\
\text { hues }^{y}\end{array}$ & $\begin{array}{c}\text { Vein } \\
\text { pattern }^{x}\end{array}$ & White \\
\hline Scarlet $^{\mathrm{w}}$ & & & & \\
\hline Sal/Sal Am/- & 4 & 82 & Absent $^{\mathrm{w}}$ & \\
\hline Intermediate red & & & & \\
\hline $\begin{array}{l}\text { Sal/sal Am/- } \\
\text { Salmon red }\end{array}$ & 11 & 255 & Present & 130 \\
\hline Sal/Sal am/am & 2 & 63 & Present & \\
\hline $\mathrm{Sal} / \mathrm{sal} \mathrm{am} / \mathrm{am}$ & 3 & 59 & Present & 27 \\
\hline $\begin{array}{l}\text { White } \\
\qquad \begin{array}{l}\text { sal/sal Am/- } \\
\text { sal/sal am/am }\end{array}\end{array}$ & 7 & & & 222 \\
\hline
\end{tabular}

zFor the data $4,11,2,3,7$ the $\chi^{2}(3: 6: 1: 2: 4)=0.407, P=0.98$.

yThe red hues include scarlet, intermediate red, and salmon red.

xFloral vein pattern expresses as a much paler red color along the veins of the wing petals.

wein pattern in $\mathrm{F}_{3}$ was absent for Sal/Sal Am/Am $\mathrm{F}_{2}$ parents but present (as seen with 15x magnification) for Sal/Sal Am/am $\mathrm{F}_{2}$ parents.

segregated for the same four flower color classes as the $\mathrm{F}_{2}$ (data not fully shown). No count data were recorded for salmon red flowers as a separate class because of the known disturbance of segregation at Sal.

Segregation in the $\mathrm{F}_{2}$ for the five expected classes of red or white flower colors (as confirmed in $\mathrm{F}_{3}$ ) gave a very good fit to the expected 3:6:1:2:4 ratio (Table 2). Aside from the Sal/Sal Am/ am class expressing scarlet (with variable expressivity) flowers, there is only one other improvement of the Table 1 genetic model provided by the $\mathrm{F}_{3}$ data, viz., the discovery that genotype Sal/sal $\mathrm{Am} / \mathrm{Am}$ also (besides Sal/sal Am/am) expresses intermediate red flower color (Table 2).

Flowers with the Sal/Sal am/am genotype and salmon red color express VPon the wing petals. With Sal/sal Am/am (or Am/Am), the VPin the intermediate red color is less distinct than with Sal/Sal am/ am, i.e., Am/am gives an intermediate (versus $A m / A m$ ) phenotype, demonstrating semi-dominant action of $A m$ on VPexpression. The eye/brain perception of color when pattern is present is an averaging of the two colors present. Thus, the overall appearance of Sal/Sal $\mathrm{am} / \mathrm{am}$ is classified as salmon red and the overall appearance of $\mathrm{Sal} / \mathrm{sal} \mathrm{Am/am}$ and Sal/sal Am/Am is intermediate red. With Sal/Sal $A m / A m$ and Sal/Sal Am/am, there is no more VP effect (without magnification), i.e., the scarlet color is uniformly distributed on the wing petals, but not with equal color intensity for the two genotypes. Line 5-593 is known to not carry $A m$ because repeated backcrosses of Sal into 5-593 (with subsequent selfing) never produced scarlet flowers in the progeny (Bassett, unpublished data).

Lamprecht (1948) reported that the gene Sal with seedcoat genotype $P C J G B v$ expresses mineral brown seedcoat color with a red haze. The $\mathrm{F}_{2}$ and $\mathrm{F}_{3}$ progenies from the cross $\mathrm{Sal} \mathrm{Am} \mathrm{Vwf}^{\mathrm{wf}}$

$\mathrm{BC}_{1} 5-593 \times v \mathrm{BC}_{3} 5-593$ (sal am) segregated not only for plants with the mineral brown seedcoats with red haze but also for plants with oxblood seedcoat color (Table 3). Oxblood is a dominant red seedcoat color controlled by the gene $R$ (Smith and Madsen, 1948), and $R$ is tightly linked to the complex $C$ locus (Prakken, 1974). $\mathrm{F}_{3}$ plants with white flowers and genotype sal/sal $v / v$ did not segregate for oxblood seedcoats, but plants with Sal/- Am/am (or am/am) $v / v$ segregated for oxblood seedcoats at a frequency significantly below the expected value for a trait controlled by a dominant gene) (Table 3, cross 1). The expected frequency is $29 R: 10 \mathrm{r}$ for the $39 \mathrm{v} / \mathrm{v}$ plants (Table 3 , cross 2 ). For the data 0 and 39 , the $\chi^{2}(3: 1)=117$, $P<0.001$. Thus, the hypothesis that $R$ is expressing the observed oxblood seedcoat color is doubtful. An alternative hypothesis is that the gene $A m$ (or a gene closely linked to $A m$ ) controls augmented expression of the red haze (pleiotropic) effect of the Sal gene to produce a seedcoat color that is indistinguishable from oxblood. $\mathrm{F}_{3}$ plants segregating for white flower color have sal/sal. Because $A m$ is unable to express with sal, there is no possibility for oxblood seedcoat color segregation among plants with white flowers if the $A m$ hypothesis is correct. The Am hypothesis also predicts that $\mathrm{F}_{3}$ plants with salmon red flowers (Sal/- am/am) will never express oxblood seedcoats. The data are not adequate to test this aspect of the hypothesis (Table 3). The shortage of plants (with Sal Am v) expressing oxblood red seedcoats (13 observed vs. 30.75 expected) is probably due to the linkage between $A m$ and $V$, which will be established below (Table 3, cross 1).

From the cross $v \mathrm{BC}_{3} 5-593$ (sal am) $\times$ Sal/Sal Am/am Vwf $/ v$ $\mathrm{BC}_{2}-\mathrm{F}_{2}$ (Am-20), $29 \mathrm{~F}_{4}$ progenies derived from an $\mathrm{F}_{2}$ parent with genotype Sal/SalAm/am $\mathrm{Vwf} / v$ were classified for flower and seedcoat color (Table 4). Because the $\mathrm{F}_{3}$ parents were classified into three Table 3. Segregation for flower and seedcoat color in 14 selected $\mathrm{F}_{3}$ progenies from the cross Sal Am $\mathrm{V}^{\mathrm{wf}} \mathrm{BC}_{1} 5-593 \times \mathrm{x}$ BC 3 5-593 (sal am): 1) eight $\mathrm{F}_{3}$ progenies with $\mathrm{F}_{2}$ parents having genotype $\mathrm{Sal} / \mathrm{sal} \mathrm{Am/am} \mathrm{Vwf}^{\mathrm{wf}} / \mathrm{v}$ and 2 ) six $\mathrm{F}_{3}$ progenies with $\mathrm{F}_{2}$ parents having genotype sal/sal $V^{\mathrm{wf}} / v$.

\begin{tabular}{|c|c|c|c|c|c|}
\hline \multirow{4}{*}{$\begin{array}{l}\mathrm{F}_{3} \\
\text { progeny } \\
\text { group } \\
\text { no. }\end{array}$} & \multicolumn{3}{|c|}{$\begin{array}{c}S a l /-A m /-(\text { or } a m / a m) \\
\text { Red flowers }\end{array}$} & \multicolumn{2}{|c|}{$\begin{array}{c}\text { sal/sal -/- } \\
\text { White flowers }\end{array}$} \\
\hline & \multirow{3}{*}{$\begin{array}{c}V^{\mathrm{wf} /-} \\
\text { Black } \\
\text { seeds }\end{array}$} & \multicolumn{2}{|c|}{$v / v$} & $V_{\text {wf/- }}$ & $v / v$ \\
\hline & & Oxblood & M.B. with & Black & M.B. \\
\hline & & seeds & r.h. seeds ${ }^{y}$ & seeds & seeds ${ }^{y}$ \\
\hline $1^{x}$ & 199 & 13 & 28 & 68 & 10 \\
\hline 2 & & & & 164 & 39 \\
\hline
\end{tabular}

zThe red flower colors include scarlet, intermediate red, and salmon red.

yM.B. = mineral brown; M.B. with r.h. = mineral brown with red haze.

xFor the data 13 and 28 , the $\chi^{2}(3: 1)=41.0, P<0.001$. 
Table 4. Segregation for flower and seedcoat color in $\mathrm{F}_{4}$ progenies from $29 \mathrm{~F}_{3}$ plants grown from remnant seed of an $\mathrm{F}_{2}$ parent with Sal/Sal Am/am $V_{\mathrm{wf}} / v$ derived from the cross $v \mathrm{BC}_{3} 5-593$ (sal am) $\times$ Sal/Sal Am/am $V_{\text {wf }} / v \mathrm{BC}_{2}-\mathrm{F}_{2} 5-593(\mathrm{Am}-20)$.

\begin{tabular}{|c|c|c|c|c|c|c|}
\hline \multirow[b]{4}{*}{$\begin{array}{l}\text { Flower color } \\
\text { of } \mathrm{F}_{3} \text { parent }\end{array}$} & \multirow[b]{4}{*}{$\begin{array}{l}\text { No. of } \mathrm{F}_{4} \\
\text { progenies }^{\mathrm{z}}\end{array}$} & \multicolumn{5}{|c|}{ Flower color } \\
\hline & & \multicolumn{3}{|c|}{$\begin{array}{l}\text { Scarlet or intermediate redy } \\
\qquad \mathrm{Sal} / \mathrm{Sal} \mathrm{Am/-}\end{array}$} & \multicolumn{2}{|c|}{$\begin{array}{c}\text { Salmon red } \\
\text { Sal/Sal am/am }\end{array}$} \\
\hline & & \multirow{2}{*}{$\begin{array}{c}V^{\mathrm{wf}} /- \\
\text { Black } \\
\text { seed }\end{array}$} & \multicolumn{2}{|c|}{$v / v$} & \multirow{2}{*}{$\begin{array}{c}V^{\mathrm{wf} /-} \\
\text { Black } \\
\text { seed }\end{array}$} & \multirow{2}{*}{$\begin{array}{r}v / v \\
\text { M.B } \\
\text { seed }\end{array}$} \\
\hline & & & $\begin{array}{l}\text { Oxblood } \\
\text { seed }^{x}\end{array}$ & $\begin{array}{l}\text { M.B. } \\
\text { seed }^{w}\end{array}$ & & \\
\hline Scarlet $^{v}$ & 4 & 111 & & & & \\
\hline Sal/Sal Am/Am & $3^{u}$ & 75 & 9 & 5 & & \\
\hline Intermediate redy & $10^{t}$ & 233 & 21 & 8 & 8 & 43 \\
\hline \multirow[t]{2}{*}{ Sal/Sal Am/am } & 6 & 132 & & 2 & 14 & 18 \\
\hline & 2 & & 31 & & & 19 \\
\hline $\begin{array}{l}\text { Salmon red } \\
\text { Sal/Sal am/am }\end{array}$ & 4 & & & & & 72 \\
\hline
\end{tabular}

zFor the observed data $7,18,4$ the $\chi^{2}(1: 2: 1)=2.310, P=0.32$.

yThe $F_{3}$ plants were classified (greenhouse) for three flower colors, but the $F_{4}$ were classified (field) only as scarlet (combined with intermediate red) or salmon red. Four $\mathrm{F}_{4}$ plots had significant disturbance of segregation at $A m\left(115,8\right.$ gave $\chi^{2}(3: 1)=22.44, P<0.001$, but $\chi^{2}(15: 1)=0.014$, $P=0.91)$; but the remaining 14 plots segregated for $312 \mathrm{Am} /$ - (other red) and $94 \mathrm{am} / \mathrm{am}$ (salmon red), giving $\chi^{2}(3: 1)=0.739, P=0.39$.

xThe genetic hypothesis for oxblood seedcoat color is $\mathrm{Sal}$ and a gene $\mathrm{Oxb}$ (tentative gene symbol) closely linked to $A m$.

wM.B. = mineral brown with a red haze due to Sal expression in the seed.

${ }^{v}$ All seven $\mathrm{F}_{3}$ parents with scarlet flowers were true breeding for flower color, but not seedcoat color.

uWith $A m / A m v / v$, the data 9,5 give $\chi^{2}(3: 1)=0.857, P=0.36$. Two of the plots segregated for mineral brown seedcoats due to a hypothetical crossover genotype Sal Am oxb.

'With Am/am v/v, the data 21,8 give $\chi^{2}(3: 1)=0.103, P=0.75$.

flower color classes and the $\mathrm{F}_{4}$ into only two flower color classes, the genotypes Sal/Sal Am/Am and Sal/Sal Am/am are combined and described as scarlet or intermediate red, respectively. All seven progenies derived from $\mathrm{F}_{3}$ parents with scarlet flower color were true breeding in $\mathrm{F}_{4}$ for scarlet flowers, i.e., the $\mathrm{F}_{3}$ parents are presumed to have genotype $A m / A m$ in the absence of salmon red progeny (Table 4, data not fully shown). Similarly, the four $\mathrm{F}_{3}$ parents with salmon red flower color were true breeding in $\mathrm{F}_{4}$ (Table 4). Fourteen of the $\mathrm{F}_{3}$ parents with intermediate red flower color segregated 3 : 1 for other red (combined scarlet and intermediate red) to salmon red flower color, whereas the remaining four intermediate red $\mathrm{F}_{3}$ parents segregated for a good fit to a 15:1 ratio for the same classes (Table 4, data not fully shown). Thus, the strong disturbance of segregation in the latter four progenies may be under genetic control by some unknown gene. There was a good fit to a 1:2:1 ratio for the three flower color classes among all the $\mathrm{F}_{4}$ progenies, viz., scarlet $(\mathrm{Am} / \mathrm{Am})$, intermediate red $(\mathrm{Am} / \mathrm{am})$ and salmon red $(\mathrm{am} /$ $a m$ ), respectively (Table 4). Thus, the data support the hypothesis that a single gene, $A m$, controls scarlet flower color in a partially dominant mode of action in the presence of Sal.

The segregation of seedcoat colors was not independent of flower color (Table 4). Oxblood red seedcoat color was usually observed only with $\mathrm{Am} /$-, but two $\mathrm{F}_{4}$ progenies from $\mathrm{F}_{3}$ parents with $\mathrm{Sal} / \mathrm{Sal} \mathrm{Am} / \mathrm{Am}$ segregated for plants having mineral brown seedcoats with red haze (MBRH seeds) (Table 4). The hypothesis is that there is a dominant gene closely linked to Am that (with Sal $v$ ) controls expression of oxblood red seedcoats. I give the tentative gene symbol $O x b$ to this hypothetical gene. Thus, the five plants with MBRH seeds segregating from parents with $\mathrm{Sal} / \mathrm{Sal} \mathrm{Am} / \mathrm{Am}$ are putative crossover events with genotype Sal Am oxb (Table 4). No tests were conducted to verify the apparent crossover genotype. If the five plants have MBRH seeds due to experimental error, the alternative hypothesis is that $A m$ has the pleiotropic effect of changing MBRH seeds to oxblood red, i.e., $O x b$ does not exist. The data were not sufficient to calculate a robust linkage estimate for $A m$ and $O x b$ (Table 4).
A shortage of plants with salmon red flowers (am/am) and black seedcoats $\left(V^{\mathrm{wf}} /-\right)$ was observed (Table 4$)$. The hypothesis is that the shortage is due to linkage between the $A m$ and $V$ loci. The data were analyzed for linkage of $A m$ with $V$ after removing 13 of the $\mathrm{F}_{4}$ progenies due to either disturbed segregation at $A m$ or $V$, or for no segregation at $V$. For the 16 remaining $\mathrm{F}_{4}$ progenies, there was no significant disturbance within loci (data not shown), and the $\chi_{\mathrm{L}}^{2}$ $=150.06, P<0.001$. For the data $180 \mathrm{Am} /-V^{\mathrm{wf}} /-, 12 \mathrm{Am} /-v / v, 11$ am/am $V$ wf/-, and $53 \mathrm{am} / \mathrm{am} v / v$ with coupling phase linkage, the map distance between $A m$ and $V$ was calculated as $\mathrm{cM}=9.40 \pm 1.93$.

Another genetic test was made to ensure that the oxblood red seedcoats were not mistaken for the close red color garnet brown (dark red kidney) expressed by the gene $r k^{\mathrm{d}}$ (Smith and Madsen, 1948). From this point forward in this paper, I will insert the hypothetical $O x b$ gene into the genotypes of the parental materials and their progenies. The $\mathrm{F}_{4}$ progenies from $\mathrm{F}_{3}$ parents with scarlet flowers and oxblood seedcoats derived from the cross $v \mathrm{BC}_{3} 5-593$ (sal amoxb) X Sal/Sal Am/am Oxb/oxb $V$ wf $/ v \mathrm{BC}_{2}-\mathrm{F}_{2} 5-593$ (Am-21) segregated in a 3:1 ratio for oxblood $(O x b /-)$ seedcoats to mineral brown $(o x b / o x b)$ seedcoats with a red haze, respectively (Table 5). The flower color data were recorded independently of the seedcoat color data and are, therefore, not presented; but segregation for salmon red flowers was observed in all plots (data not shown). The

Table 5. Segregation for seedcoat color in $F_{4}$ progenies from seven $F_{3}$ parents with scarlet flowers and oxblood seeds due to $\mathrm{Sal} / \mathrm{Sal} \mathrm{Am/am}$ Oxb/oxb $v / v$ derived from the cross $v \mathrm{BC}_{3}$ 5-593 (sal am oxb) $\times$ Sal/Sal Am/am Oxb/oxb $V^{\mathrm{wf}} / v \mathrm{BC}_{2}-\mathrm{F}_{2} 5-593(\mathrm{Am}-21){ }^{\mathrm{z}}$

\begin{tabular}{lccc}
\hline Oxblood seeds & $\begin{array}{c}\text { Mineral brown seedsy } \\
\text { oxb/oxb }\end{array}$ & $\chi^{2}(3: 1)$ & $P$ \\
\hline $8 x b /-$ & 28 & 0.046 & 0.83
\end{tabular}

${ }^{2}$ The hypothesis is that oxblood color is controlled by a dominant gene (closely linked to $A m$ ), which has the tentative gene symbol $O x b$. Flower color segregation (data recorded independently of seed color) was classified as salmon red (am/am) vs. other red $(\mathrm{Am} /-)$ due to segregation at Am (data not shown).

yAll seeds had the red haze expressed by Sal. 
Table 6. Expression of the genes $\mathrm{Sal}$ and $\mathrm{Am}$ in the presence of $v / v$ for flower color.

\begin{tabular}{|c|c|c|}
\hline Genotype & Frequency & Flower color \\
\hline$\overline{\mathrm{Sal} / \mathrm{Sal} \mathrm{Am} / \mathrm{Am}}$ & 1 & Scarlet $^{z}$ \\
\hline Sal/Sal Am/am & 2 & Scarlet or intermediate redy \\
\hline Sal/Sal am/am & 1 & Salmon red ${ }^{x}$ \\
\hline $\mathrm{Sal} / \mathrm{sal} \mathrm{Am/Am}$ & 2 & Intermediate redy \\
\hline $\mathrm{Sal} / \mathrm{sal} \mathrm{Am/am}$ & 4 & Intermediate redy \\
\hline $\mathrm{Sal} / \mathrm{sal} \mathrm{am/am}$ & 2 & Salmon redx \\
\hline $\mathrm{sal} / \mathrm{sal} \mathrm{Am/Am}$ & 1 & White \\
\hline $\mathrm{sal} / \mathrm{sal} \mathrm{Am/am}$ & 2 & White \\
\hline $\mathrm{sal} / \mathrm{sal} \mathrm{am/am}$ & 1 & White \\
\hline
\end{tabular}

zThe genotype $\mathrm{Sal} / \mathrm{Sal} \mathrm{Am/Am}$ is completely free of floral vein pattern (pale red color in the wing petal veins). Scarlet matches $43 \mathrm{C}$ on Royal Horticultural Society (RHS) Color Fan 1.

yThe genotype $\mathrm{Sal} / \mathrm{Sal} \mathrm{Am} / \mathrm{am}$ has very weak vein pattern (visible with $15 \times$ magnification) and is difficult to distinguish from Sal/Sal Am/Am. The intermediate red color class is highly variable due to the variability of vein pattern expression among the three genotypes expressing this color.

xSalmon red matches $52 \mathrm{C}$ or D on RHS Color Fan 1.

oxblood seedcoat color acts like a dominant trait, for which the controlling gene was heterozygous in the $\mathrm{F}_{3}$ parents. If the oxblood seedcoat color was really a mis-classification of the garnet brown expressed by $r k^{\mathrm{d}}$, then one would expect the $\mathrm{F}_{4}$ progenies to be true breeding for the dark red seedcoat color observed. The dark red seedcoat color was not true breeding (Table 5); therefore, the $R k$ locus cannot be involved.

The genetic hypothesis is that oxblood seedcoat color is controlled by $O x b$ (closely linked to $A m$ ), which augments red seedcoat color expression from the red haze of Sal am oxb v to oxblood with $\mathrm{Sal}$ Am Oxbv (Table 5). Oxblood red seedcoat color was first reported by Smith (1939). Oxblood is a dominant red seedcoat color controlled by the gene $R$ within the complex $C$ locus (Bassett, 1991; Prakken, 1974; Smith, 1939; Smith and Madsen, 1948). In the experimental materials derived from M0169 (as presented above), oxblood seedcoat color is achieved by a different genotype. This conclusion is supported by linkage information. As shown above, $A m$ and $V$ are linked $(\mathrm{cM}=9.4)$, whereas the $C$ and $V$ loci are independent (McClean et al., 2002). Thus, the $O x b$ gene symbol cannot be a synonym for $R$.

Summary OF INTERACTIONS BETWEen $\boldsymbol{A m}$ AND $\mathrm{Sal}$. The genotype $\mathrm{Sal} / \mathrm{Sal} \mathrm{Am} / \mathrm{Am}$ expresses scarlet flower color without VP. Using the new system of color fans provided by the RHS Fans, scarlet matches $43 \mathrm{C}$ on Fan 1. Sal/Sal Am/am expresses either scarlet or a very close hue (darkest expression of intermediate red) without VP that cannot always be unambiguously classified with respect to scarlet, even under favorable greenhouse conditions. The genotypes $\mathrm{Sal} / \mathrm{Sal} \mathrm{Am/-} \mathrm{can}$ be identified reliably in the field in full sunlight by the fluorescent quality of the scarlet color; however, genotype Sal/sal Am/Am cannot be unambiguously classified in the field by iridescence (data not shown). The selection can be made while standing and looking down the plot row, which relieves one from having to pick a flower from each plant and match it to a color chart. Under greenhouse conditions, the genotypes $\mathrm{Sal} / \mathrm{sal} \mathrm{Am/-} \mathrm{express} \mathrm{intermediate} \mathrm{red} \mathrm{with} \mathrm{VP.}$ The genotypes Sal/- am/am express salmon red flower color with strong VP, which matches $52 \mathrm{C}$ or D on Fan 1 of the RHS Fans. The distinction between salmon red and all other red colors can be made easily and reliably in the greenhouse or field without picking flowers and matching to a color chart. Genotype sal/sal with $v / v$ or $V$ wf/- expresses white flowers, regardless of the genotype at $A m$. The interactions of Sal and Am for flower color expression are summarized (Table 6). Thus, the change of genotype from Sal am v to Sal Amv has two pleiotropic effects: flower color change from salmon red to scarlet and VP change from present to absent.

Sal has pleiotropic dominant red color expression in both flowers and seedcoats (Lamprecht, 1948). With Sal v or $V^{\mathrm{wf}}, A m$ has partially dominant gene action in flowers, changing salmon red to scarlet. With $P[C r] J G B v / v, S a l /$ - expresses mineral brown seedcoats with a red haze, where the red haze is especially strong around the caruncula and hilum area in general. There is a linkage of approximately 9 $\mathrm{cM}$ between $\mathrm{Am}$ and $V$. Consequently, during the introgression of Sal Am $V^{\text {wf }}$ from M0169 into the 5-593 genetic background, using $v \mathrm{BC}_{3} 5-593$ as the recurrent parent, there was an obvious linkage drag involved in the deliberate selection of scarlet flowers $(\mathrm{Am})$ and the fortuitous selection for black seedcoats expressed by $V^{\mathrm{wf}}$. In early stages of inspection of the data, $V^{\mathrm{wf}}$ appeared to be necessary for scarlet flower expression, but upon complete analysis of the data the linkage hypothesis, and not epistasis, was better supported by the data as the cause of the strong association.

There is a very close association between $\mathrm{Am}$ and oxblood red seedcoat color, but five plants were observed with Sal Amv while expressing MBRH seedcoats (Table 4). The hypothesis is that oxblood seedcoat color is controlled by the gene $O x b$, which is closely linked to the flower color gene $A m$. Thus, the five plants with MBRH seedcoats are putative crossover products with genotype Sal Am oxb $v$. The five plants were not tested to confirm their putative crossover status; hence, the supporting data are still tentative and no formal gene symbol proposal is appropriate. Also, the data were not sufficient to calculate a robust estimate of linkage distance between $A m$ and $O x b$. Until putative crossover events between $A m$ and $O x b$ (Table 4 ) are confirmed by further research, the alternative hypothesis that Am (with Sal v) expresses oxblood seedcoat color remains as a possible additional pleiotropic effect of $\mathrm{Am}$.

\section{Literature Cited}

Allard, R.W. 1956. Formulas and tables to facilitate the calculation of recombinational values in heredity. Hilgardia 24:235-278.

Bassett, M.J. 1976. The inheritance of the reclining foliage character in beans and its potential value when combined with long racemes. HortScience 11:238-240.

Bassett, M.J. 1991. A revised linkage map of common bean. HortScience 26: 834-836.

Bassett, M.J. 1994. The genotype for seedcoat color of breeding line 5-593. Annu. Rpt. Bean Improvement Coop. 37:244-245.

Bassett, M.J. 1996. A complex $C$ region genotype [? R] that with $G B$ vae produces dark seal-brown seedcoat color in common bean. J. Amer. Soc. Hort. Sci. 121: 594-598.

Bassett, M.J. 1997. A new allele ( $\left.V^{\mathrm{wf}}\right)$ at the $V$ locus for flower and seedcoat color in common bean. J. Amer. Soc. Hort. Sci. 122:519-521.

Bassett, M.J., X. Lin-Bao, and C. Hannah. 1990. Flower colors in common bean produced by interactions of the $S a l$ and $V$ loci and a gametophyte factor $G a$ linked to Sal. J. Amer. Soc. Hort. Sci. 115:1029-1033.

Lamprecht, H. 1940. Die Artgrenze zwischen Phaseolus vulgaris L. und multiflorus Lam. Hereditas 27:51-175.

Lamprecht, H. 1948. On the effect of linkage of genes transmitted from Phaseolus coccineus to Ph. vulgaris. Agr. Hort. Genet. 6:64-81.

Mather, K. 1957. The measurement of linkage in heredity. 2nd ed. Wiley, New York

McClean, P.E., R.K. Lee, C. Otto, P. Gepts, and M.J. Bassett. 2002. Molecular and phenotypic mapping of genes controlling seed coat pattern and color in common bean (Phaseolus vulgaris L.). J. Hered. 93:148-152.

Prakken, R. 1974. Inheritance of colours in Phaseolus vulgaris L. IV. Recombination within the 'complex locus C'. Meded. Landbouwhogeschool Wageningen 74-24.

Smith, F.L. 1939. A genetic analysis of red seed-coat color in Phaseolus vulgaris. Hilgardia 12:553-621.

Smith, F.L. and C.B. Madsen. 1948. Seed-color inheritance in bean. J. Hered. 39: 191-194. 